\author{
Magdalena Perkowska \\ University of Bialystok

\section{Emilia Jurgielewicz} \\ University of Bialystok
}

\title{
THE PROBLEM OF LANGUAGE IN THE PROCEDURE FOR GRANTING REFUGEE STATUS
}

\begin{abstract}
Refugees constitute one of the most serious international problems that the world faces today. The problem of guarantee of access to a language that is understood by the applicant in the procedure for granting refugee status, presented in this paper, is strongly associated with this matter. Due to the fact that this is an issue which affects a considerable number of states, both international and domestic regulations concerning the granting of refugee status were selected for examination in the present paper. The provisions of the Convention relating to the Status of Refugees, the Convention for the Protection of Human Rights and Fundamental Freedoms, as well as of the Act of 13 June 2003 on granting protection to foreigners within the territory of the Republic of Poland were considered. The paper focuses on an analysis of the guarantee to make provision for communication in an understandable language, which does not create a barrier for the person applying for refugee status while communicating with administrative agencies that are decisive in granting the aforementioned status.
\end{abstract}

Keywords: language, refugee, human rights

The United Nations High Commissioner for Refugees considers it necessary to provide information to persons in need of international protection in a language which they understand. As a matter of principle, every effort to do so should be made by host countries. Assumptions, for example, that an asylum - seeker speaks or understands the official language of his or her country of origin, may prove incorrect.

(UNHCR, 2003)

The practice of granting asylum to people fleeing persecution in foreign lands is one of the earliest hallmarks of civilization. References to it have been found in texts written 3,500 years ago, during the blossoming of the great early empires in the Middle East such as the Hittites, Babylonians, Assyrians and ancient Egyptians. 


\section{Magdalena Perkowska and Emilia Jurgielewicz}

However, Amnesty International claims that, for example, in 2012 rights of millions of people who fled to avoid conflicts and persecution or migrated to find work and a better life for themselves and their families were infringed. The organization accuses governments all over the world of being far more interested in protecting their borders, than the people and human rights attributed to them (Amnesty, 2012). Therefore, it is crucial not only to guarantee that the right to be free from persecution is respected but also to ensure a fair procedure for granting the status of refugee in domestic legal systems.

One should bear in mind that in the case of foreigners who come to Poland and decide to apply for the status of refugee, the procedure itself constitutes a problem. Firstly, it is completely strange to them and the language and cultural barriers may prove an additional hindrance, putting foreigners in an inferior position in their dealings with Polish administrative authorities. There are several stages to the procedure for granting the status of refugee at which a foreigner might feel powerless and lost without professional assistance. Secondly, a particularly thorny issue is that of lack of knowledge of the local language. Even those who have mastered Polish complain that the language used in application forms and other documents which they are required to complete is too formal and hence incomprehensible and unclear. Foreigners declare that they would like to obtain information which is indispensable to their daily lives in their own native language (Peda, 2006).

Thus, the present paper endeavours to analyse international and domestic acts of law concerning the guarantee for the provision of an understandable language for those involved in the procedure for granting refugee status.

\section{The Convention relating to the Status of Refugees}

The Convention was approved at a special United Nations conference on 28 July 1951. It entered into force on 22 April 1954 (hereinafter CRSR). It was initially limited to protecting European refugees after World War II, but a 1967 Protocol removed the geographical and time limits, expanding the Convention's scope (UNHCR, 2001). The Convention relating to the Status of Refugees is the key legal document in defining who is a refugee, their rights and the legal obligations of states (Wierzbicki, 1993; Florczak, 2009).

In accordance with Art. 1 (A) (1), a 'refugee' is

a person who owing to well-founded fear of being persecuted for reasons of race, religion, nationality, membership of a particular social group or political opinion, is outside the country of his nationality and is unable or, owing to such fear, is unwilling to avail himself of the protection of that country; or 
who, not having a nationality and being outside the country of his former habitual residence as a result of such events, is unable or, owing to such fear, is unwilling to return to it.

Applying for the status of refugee under the CRSR is conditional upon the fact that a refugee has moved between at least two countries either on the same continent or in the world. A foreign national is a person who is not a citizen of the host country in which he or she is residing or temporarily sojourning. S/he frequently does not speak the language of the country in which s/he applies for refugee status, which raises the problem of whether the guarantee of access to the language that is understood by the applicant is provided. Neither the 1951 Geneva Convention nor the 1967 Protocol include the provisions on a language in the procedure for granting the status of refugee, which would guarantee the fairness of the aforesaid procedure.

\section{Convention for the Protection of Human Rights and Fundamental Freedoms (European Convention on Human Rights - ECHR)}

The Convention for the Protection of Human Rights and Fundamental Freedoms of 4 November 1950 is an international act including, inter alia, some guarantees in the proceedings. The ECHR comprises a universal catalogue of rights and freedoms granted to every human being but it does not include an expressis verbis right which could be broadly named the 'right to a language', hence it does not mention the language of the procedure for granting the status of refugee. The Convention, however, does not remain silent as far as the issue of language is concerned. Its creators realized that a fair trial is a trial which does not raise any doubts among the parties. Therefore, it should be comprehensible for the people involved (like refugees) who do not speak the language of the country in which they are staying. Accordingly, the authors of the present paper decided to examine two legal instruments on language included in the European Convention on Human Rights: Art. 5 (2) of the ECHR guaranteeing the right to liberty and security, and Art. 6 of the ECHR ensuring the right to a fair trial.

Article 5 ECHR - Right to liberty and security

(...)

2. Everyone who is arrested shall be informed promptly, in a language which he understands, of the reasons for his arrest and of any charge against him. (...) 


\section{Magdalena Perkowska and Emilia Jurgielewicz}

Art. 5 (2) of the ECHR includes an important guarantee provided to all people deprived of liberty (Oleksiewicz, 2006). The right to be informed, which is conferred on every person deprived of liberty regardless of the grounds and the time of his/her detention, is the essence of this guarantee. The requirement to provide such a person with the aforementioned information is grounded in the command to treat every human being in a humanitarian way. A person deprived of liberty should be aware of his/her present status and likely fate. Only a person who has full knowledge of the reasons for his/her detention and of the allegations against him/her may accurately assess whether $\mathrm{s} /$ he needs to use the right to challenge this detention in court.

The aforementioned provision states that any information should be provided 'promptly'. This requirement is crucial principally in the context of the guarantees in the proceedings which are provided to the person who has been detained and which cannot be carried on if a detained person does not possess knowledge of why s/he has been detained. Obviously, the term [mentioned in Art. 5 (2) of the ECHR] commences from the moment when the person has de facto been detained. Therefore, no obligation arises under Art. 5 (2) to inform the person detained on the grounds and reasons for a person's detention and the charges against him/her if the decision to arrest him/her was made due to, for example, an arrest warrant. This information, which is official confirmation that such a person has been deprived of liberty, must include the reasons for the detention and charges against the person detained. It is noteworthy to say that lack of this confirmation would be a denial of the guarantee of personal freedom and would be the most serious infringement of Art. 5 of the ECHR and a hindrance to control the legality of detention. Therefore, it is required that the information includes the grounds for detention and the content of charges against the detained. The examined Art. 5 (2) of the ECHR does not stipulate any requirements as regards the form this information should take, merely stating that it should be provided in a language which is comprehensible to the detained. This means that the information may be given in any form, either in writing or orally. It is assumed sufficient that the arrested person was served an arrest warrant explaining the reasons for arrest in writing, or even that such a warrant is served and the grounds for the arrest are given orally. It needs to be highlighted here that the guarantee arising from Art. 5 (2) is not infringed if the detained person was familiar with the reasons for his/her arrest due to the fact that they were isseminated widely within international community.

The requirement to provide the detained with information in the language $\mathrm{s} /$ he understands does not mean however, that every person who has 
been detained and does not understand the language used by the detaining authority has the right to the free assistance of an interpreter. This requirement should be perceived in broad terms i.e. the information should be provided in such a way so that it is understood by the informed party - also in a form or content which is adjusted to the intellectual level of the detained. Hence, it may be assumed that when the detained is not able to understand the message conveyed, her/his legal representative or guardian needs to be informed (Hofmański, 2010).

Article 6 ECHR - Right to a fair trial

(...)

3. Everyone charged with a criminal offence has the following minimum rights: (...)

e. to have the free assistance of an interpreter if he cannot understand or speak the language used in court.

Before considering the right to free assistance of an interpreter stipulated in Art. 6 (3) (e) of the ECHR it is worth noting that this right is one of the numerous guarantees to a fair trial which are defined in Art. 6 of the Convention for the Protection of Human Rights and Fundamental Freedoms. In section 1 of the aforementioned article a general principle (which may be applied widely) is stated, which guarantees the right to a fair i.e. just and public hearing before the court. It occupies a crucial position in any democratic state and is of key importance for democracy to function properly and therefore cannot be interpreted narrowly. This right complements the right to an independent and impartial tribunal, established by law. Moreover, the rights arising from Art. 6 (1) reflect the principle of subsidiarity, according to which national courts and tribunals are primarily obliged to protect the rights and freedoms of individuals whereas Art. 6 (2) of the ECHR includes the principle of presumption of innocence: "everyone charged with a criminal offence shall be presumed innocent until proved guilty according to law". The final section of Article 6 lists five fundamental rights (elements of a fair trial) stating that everyone charged with a criminal offence has the following minimum rights:

a) to be informed promptly, in a language which he understands and in detail, of the nature and cause of the accusation against him;

b) to have adequate time and facilities for the preparation of his defence;

c) to defend himself in person or through legal assistance of his own choosing or, if he has not sufficient means to pay for legal assistance, to be given it free when the interests of justice so require; 
d) to examine or have examined witnesses against him and to obtain the attendance and examination of witnesses on his behalf under the same conditions as witnesses against him;

e) to have the free assistance of an interpreter if he cannot understand or speak the language used in court.

Let us concentrate on the right to have the assistance of an interpreter, which is crucial in the context of the present article and which naturally complements lawsuit guarantees arising from Art. 6. The provision of these guarantees would be hindered, or even impossible if the accused did not speak the language of the country in which the proceedings are conducted. It also aims to prevent a situation in which the accused who does not speak the official language of the country, is in an inferior position in comparison to others who may have been accused, who speak the language. It may then be concluded that if the accused has an effective right to take part in criminal proceedings, the participation of an interpreter is indispensable. The right protected by Art. 6 (3) (e) of the ECHR includes the right to the free assistance of an interpreter for any person who cannot speak or understand the language used in court without the need to reimburse the costs of translation and/or interpretation covered by the state (Nowicki, 2001).

The right to the assistance of an interpreter is a simple consequence of the fact that the accused was not provided with the possibility of using either his/her native language or any other language that s/he understands or speaks during hearings and trials or uses in pleadings or writs. It is assumed that such a position is neither feasible nor convenient. One cannot require that all proceedings before any court are conducted in the language that the accused understands or speaks.

The right to have the assistance of an interpreter can be analysed from two different perspectives, depending on the role the interpreter plays in the proceedings. Firstly, the participation of an interpreter may be connected with the process of gathering evidence, or situations in which the evidence cannot be used as it is in a foreign language or while interrogating witnesses who do not speak the language used in court. Secondly, the accused may use lawsuit rights which are stipulated in the code of procedure provided $\mathrm{s} /$ he can understand the language used by investigation officers or in court (Hofmański \& Wróbel, 2010).

The aforementioned provision guarantees the right to use the assistance of an interpreter in two situations: either when the accused does not understand or speak the language. If the accused has sufficient competence to understand and speak the language used in court, s/he is not provided with this assistance. This does not only require ordinary language competence. 
Also those who, due to their physical disability, cannot hear or speak and who cannot participate in the hearings properly without special help from other people, are provided with this assistance.

The obligation to provide the free assistance of an interpreter is not determined by the material status of the accused. Interpreting/translating is one of the measures which states are required to provide in criminal lawsuits to comply with the obligations imposed by Art. 6 of the ECHR. The accused is not obliged to cover the costs of translation/interpreting, even in the case of his/her conviction. Any other interpretation would contradict the objectives set out in Art. 6 of the ECHR, which are to ensure that the right to a fair trial is respected. In other circumstances, the accused may renounce the right to an interpreter for the sole reason of excessive financial burden (Nowicki, 2001:65).

The aforementioned rights are contained in the article which refer to an accused person's rights in criminal proceedings. In the authors' opinion, the right to a fair trial included in Art. 6 of the ECHR also covers the general principle of fair conduct in every procedure, including the procedure for granting refugee status (Wróbel, 2010). It would seem to be sound reasoning, as frequently it is those people who communicate solely with the help of an interpreter, who participate in this procedure.

\section{Act of 13 June 2003 on granting protection to foreigners within the territory of the Republic of Poland (Journal of Laws of 2003, No 128, item 1176, hereinafter Foreigners Protection Act)}

The Polish procedure for granting refugee status is of an administrative character. The application, although submitted to the Head of the Office for Foreigners, includes elements of judicial proceedings, as in an appeal procedure or in the procedure to place an applicant in a guarded centre or under arrest for the purpose of expulsion.

A foreigner who wishes to obtain international protection in the Republic of Poland should declare his/her intention to submit this kind of petition to the Border Guard officers during border controls. If a foreigner has already entered the territory of the Republic of Poland and wishes to submit an application for refugee status, s/he has to do so through the commanding officer of the Border Guard division, with authority for the City of Warsaw. The application to grant protection is submitted in person to the Head of the Office for Foreigners through the commanding officer of the Border Guard checkpoint. If a foreigner is accompanied by minor 


\section{Magdalena Perkowska and Emilia Jurgielewicz}

children his/her petition also applies to them, or may be applied to the applicant's spouse, if he/she grants his/her permission in writing. A person who applies for refugee status has to complete an appropriate form in a language that $\mathrm{s} /$ he speaks or understands. This application form includes data relevant to the applicant and/or to the person on whose behalf $\mathrm{s} / \mathrm{he}$ is applying for this status, indication of the country of origin and important circumstances which have resulted in the application. Simultaneously, the authority to which this application is submitted is obliged to determine the applicant's identity, his/her education and language competences. Additionally, the authority is required to obtain a photograph and fingerprints of the applicant (people over 14), conduct a medical examination and provide indispensable sanitary treatments for the applicant's body and clothes. It is worth mentioning here that when necessary, the authority responsible for the procedure for granting refugee status or asylum, should translate any documents produced in Polish, which are admissible as evidence in this procedure [Art. 11 (1) of the Foreigners Protection Act] (Stachańczyk, 2006).

When submitting an application, an alien is informed about the rights that are granted to him/her and obligations imposed, as well as the legal effects of non-performance of these while staying in the territory of the Republic of Poland. In addition, s/he is also informed about the course of the procedure for granting him/her the status of refugee. All the information is provided in a language which is understandable to the applicant and also refers to the people accompanying him/her (Chlebny, 2011; Mikołajczyk, 2004). The notices in the procedure for granting refugee status, are delivered to the applicant. All correspondence for the person applying for the refugee status, whose place of residence is the centre for foreigners, is delivered by the head of the centre, and receipt must be confirmed in writing [Art. 26 (2) of the Foreigners Protection Act]. The head of the centre is required to announce receipt of correspondence addressed to the foreign national together with information about the time and place at which it may be collected by means of an information board at the centre in a language understandable to the foreigner. The correspondence is considered to have been delivered after 7 days from the day that the announcement is made [Art. 26 (5) of the Foreigners Protection Act]. Moreover, the authority responsible for the proceedings is obliged to ensure the free assistance of an interpreter, who has command of a language understandable to the applicant [Art. 43 (4) of the Foreigners Protection Act].

States use a range of methods to determine identity, drawing, for example, upon state-of-the-art technology (e.g. biometric analyses) and sophisticated databases of identity-related data. Where fingerprints and pho- 
tographs fail to identify an applicant, alternative methods may be applied, such as interviews containing knowledge-tests tailored to the presumed country of origin, and language tests conducted by experts (European Migration Network [EMN], 2013).

The Polish legislation includes more detailed provisions concerning the process for establishing identity, by setting out which methods can be applied, as well as the specific steps to be undertaken. Language analysis is an optional method to establish the identity of applicants for international protection in Poland (EMN, 2013).

Language analysis is carried out by a translator/interpreter who is a native speaker of the given language; however, since there is no specialised unit within the Office for Foreigners for carrying out such analyses, this depends on the availability of human and financial resources.

The Office for Foreigners has established cooperation with a Swedishbased company Verified, which provides language analysis services (Ministry of Interior [MI], 2012).

If the person being considered for refugee status holds a foreign passport, it is deposited through the Border Guard at the Head of the Office for Foreigners. A foreign national receives the provisional identity certificate of an alien (PICA) issued by the commanding officer of the unit, which is valid for a 30-day period from the issuance date. It is an identity card which allows the foreigner to travel within the territory of the Republic of Poland. A subsequent PICA is issued by the Head of the Office on request and is valid no longer than 6 months from the issuance date (Rafalik, 2012).

Polish regulations stipulate several kinds of procedures which may be implemented in the proceedings for granting the status of refugee. It is worth mentioning that in accordance with the provisions of the Act, instigating proceedings results in, by virtue of law, cancellation of a visa issued to an alien, expiry of any decision concerning the obligation to leave the territory of the Republic of Poland, suspension of execution of the decision on expulsion - until such date on which a foreigner is delivered a final decision on the granting of refugee status. However, the provisions on suspension of the decision on expulsion are not applicable to foreigners who, after obtaining a decision on expulsion, submit another application for granting of refugee status, unless the Head of the Office for Foreigners suspends its execution (at the foreigner's request). Art. 50 states that the authority rendering decisions in the procedure for granting refugee status is obliged to inform the applicant in writing and in a language understandable to him/her about the result of such proceedings, as well as the course and time limit for submitting any complaints. 
In accordance with Art. 80a of the Foreigners Protection Act, a foreigner admitted to the centre for foreigners should be informed about the rights conferred on him/her and any obligations imposed in a language that is understandable to him/her. In addition, s/he should be informed about the provisions on providing assistance to foreigners applying for refugee status and the rules of stay in the centre.

The possibility for lodging complaints and motions by a foreigner to the Head of the Office on the functioning of the centre and conditions of stay, in his/her native language, is an important guarantee provided to foreigners under Art. 82a of the Foreigners Protection Act.

The procedure for granting refugee status is a lengthy process, lasting even up to a year, so the ability to communicate in Polish is crucial to function in Polish society. The legislator has met this need halfway by introducing (within the welfare system) the possibility of learning Polish (with the provision of indispensable learning aids) free of charge. This is extremely important, considering a foreigner's prospective settlement in Poland and his/her further functioning in Polish society.

\section{Conclusions}

The problem of guaranteeing access to a language that is understood by the applicant in the procedure for granting refugee status is present in numerous countries which provide protection to people who are persecuted. It is the consequence of a lack of clear and precise international legal solutions, which would oblige states to guarantee the right to provision of communication in an understandable language in the procedure for granting refugee status. Both the Convention relating to the Status of Refugees, and the Convention for the Protection of Human Rights and Fundamental Freedoms remain silent in this respect. Nevertheless, in the authors' opinion, Art. 6 of the ECHR which includes the guarantee of a fair trial and refers to criminal procedures, should have wider application and become the basis for national solutions, relating also to the procedure for granting refugee status.

The authors are pleased to note that in the Republic of Poland, it is the Act on granting protection to foreigners within the territory of the Republic of Poland that includes language guarantees provided to people applying for the status of refugee. These rights comprise: informing an alien about the principles and procedures for granting refugee status in a language understandable to him/her, the possibility of submitting an application in an 
understandable language, the provision of free assistance from an interpreter or the right to learn Polish, free of charge. It seems that in introducing these provisions, the Polish legislator predicted that language or the need for an interpreter would play a crucial role in the procedure for granting refugee status. Consequently, it can be stated that Polish law includes sufficient guarantees in terms of language guarantees in the procedure for granting refugee status, and hence the fairness of a trial has been preserved.

\section{R E F E R E N C E S}

\section{LEGAL SOURCES:}

UNHCR (2003). Annotated Comments on Council Directive 2001/55/EC of 20 July 2001 on minimum standards for giving temporary protection in the event of a mass influx of displaced persons and on measures promoting a balance of efforts between Member States in receiving such persons and bearing the consequences thereof.

The Convention relating to the Status of Refugees on 28 July 1951.

Convention for the Protection of Human Rights and Fundamental Freedoms on 4 November 1950.

Act of 13 June 2003 on granting protection to foreigners within the territory of the Republic of Poland.

\section{BOOKS AND ARTICLES:}

Amnesty International Report 2013 the State of the World's Human Rights, (2012).

Chlebny, J. (2011). Postępowanie w sprawie o nadanie statusu uchodźcy, Warszawa, C. H. Beck.

European Migration Network (EMN). (2013). Establishing Identity for International Protection: Challenges and Practices.

Florczak A. (2009). Ochrona praw podstawowych w Unii Europejskiej. Warszawa: Wydawnictwa Akademickie i Profesjonalne.

Hofmański, P. \& Garlicki, L. (Ed.) (2010). Konwencja o Ochronie Praw Człowieka i Podstawowych Wolności. Komentarz do artykułów 1-18. Tom I. Warszawa: C. H. Beck.

Mikołajczyk, B. (2004). Osoby ubiegajace się o status uchodźcy. Ich prawa i standardy traktowania. Katowice: Wydawnictwo Uniwersytetu Śląskiego.

Ministry of Interior (MI). (2012). Establishing Foreigners' Identity for International Protection. Challenges and Practices National contribution from Poland.

Nowicki, M. A. (2001). Europejski Trybunat Praw Człowieka. Orzecznictwo. Tom I Prawo do rzetelnego procesu sądowego. Kraków: Zakamycze.

Oleksiewicz, I. (2006). Uchodźcy w Unii Europejskiej. Bydgoszcz, Rzeszów: Oficyna Wydawnicza Branta. 


\section{Magdalena Perkowska and Emilia Jurgielewicz}

Peda, M. D. (2013). Procedura nadania statusu uchodźcy. Gazeta Uchodźcy refugee.pl. Retrieved November 2013, from http://www.refugee.pl/cms/site. files/File/numery\%20archiwalne\%20refugee/1_GAZETA-POL.pdf.

Rafalik, N. (2012). Cudzoziemcy ubiegający się o nadanie statusu uchodźcy w Polsce - teoria a rzeczywistość (praktyka), stan prawny na dzień 31 grudnia 2011 r. CMR Working Papers, 55/113, 25.

Stachańczyk, P. \& Chlebny, J. (Ed.) (2006). Prawo o cudzoziemcach. Warszawa: C. H. Beck.

UNHCR - United Nations High Commissioner for Refugees (2001). The Refugee Convention at 50... Refugees 2001, Vol. 2, 123, 2-8.

Wierzbicki, B. (1993). Uchodźcy. Białystok: Temida2.

Wróbel, A. (2010). Konwencyjne gwarancje proceduralne w sprawach uchodźców. In T. Gardocka \& J. Sobczak (Eds.), Uchodźcy w Polsce i Europie (p. 92). Toruń: Adam Marszałek. 